\title{
The effectiveness of Washback for Learning Activities for Vocational Studies: A study of Language Assessment in an Indonesian Polytechnic
}

\author{
Nurul Fadillah \\ Staf Pengajar Bahasa Inggris Jurusan Teknik Elektro, Politeknik Negeri Pontianak \\ Email: nurul.adelaide82@gmail.com
}

\begin{abstract}
Regarding the importance of English for international communication, Indonesian government set up the regulation and included English in the curriculum for schools. English accordingly should be taught from junior high school to university level. Some primary schools in Indonesia even put English as their optional subject beginning in the third year. The regulation may lead to the improvement of human resources especially in education sector because the government believes that will develop national prosperity. In addition, it is also important to improve educational subjects (person who take part in education) for instance teacher, students, academics, etc to maintain the quality in educational sector. The research discusses the effectiveness of using washback to introduce the use of test influences on language teachers and learners activities in the classroom and also examine the concept of washback and language assessment as the instances of the consequential aspect of validity, authentic and direct assessment and difficulty in the test.
\end{abstract}

Keywords: washback, assessment, effectiveness, validity, education, test

\section{Research Background}

In the globalisation era, the importance of learning international languages has an impact in the demand of learning language. The most powerful language in the world is English, in respect to the worldwide spread of using English as the language for daily conversation. For many countries, English is used as a second language and there are some countries which used English as a foreign language, one of which is Indonesia that decides the use Bahasa Indonesia as the first or national language.

English as a Foreign Language (EFL) teachers have recognised the importance of the principal dimensions concerningthe second language communication. Indeed, second language learning may surpass the limits of memorizing particular vocabulary and grammatical rules. This research will focus on the adult learners, in this case vocational studies at State Polytechnic of Pontianak. The task objectives are to construct communicative language testing to provide a useful basis for defining the area of competence to be tested. (Antoniazzi, María I. Casado, 2012) 
Increasing learners' motivation and performance have always been the major concern of language teachers. This phenomenon may lead to the provision ofthe students' interests in learning language so that they can achieve particular objectives stated in the curriculum.

Therefore, it is very important to measure learning outcomes as a result of learning process. Test or assessment is consideredan appropriate tool to examine the effectiveness of the learning activities in the classroom. There is, however, a consideration on when to discuss the test or assessment such as test preparation and the components including into the assessment criteria (scoring system). However, the connectivity of assessment and the scoring system should balance and influence the result of learning outcome.

\section{Research Questions}

This research is concerned with the following issues:

1. What are the criteria of effective and good assessment?

2. To what extent does washback provide great implication for teaching and learning activities?

\section{Literature Review}

\section{The Nature of Washback}

Washback hasimpacted on the positive and negative sides of the examination on a particular area course content, teachers' methodology, teacher and students' attitudes, and learning. Munoz \& Alvarez (2010 stated that the phenomenon of classroom assessment could be different from the standard or particular testing system regarding the format and the purposes for which they are used before. Some assessment may have positive impact as a result of good score and some may have negative impactsresulting from low score.

When learning a language, it is important to know what the language is and what aspects have become parts ofthe language itself. To know a language means to know a language to communicate with other without thinking about the specific aspect in the language. Language is used to assess everything, for example, when you learn something you need to assess using language.

Meanwhile, learning a language also mean understanding the language, In order to be able to communicate, it means we are able to (read, speak, listen and write) the language. In short, it is important to know and learn a language by comprehending the specific 
components in the language. In this case, learning English in detail is more important to the students. This research provides the assessment to measure the students' abilities in comprehend the pictures through the given instruction by applying content-based syllabus because the students are adult learners with less English background so that they can learn by doing the tasks as a result slow process.

In another instance, Ellis (2003) believes that task based assessment could value the students' abilities in a second language (L2) from target language (L1). Therefore, he also explains the advantage of the assessment as a tool for both teacher and the students in respect to washback effect.Thiscan measure the progress and achievement in learning process. However, occasionally, stated learning outcomes are different from actual learning outcomes. It needs mutual relationship between the teacher and the students in terms of making the learning successful learning process.

\section{The Significance of Washback}

The term 'backwash' refers to the way a test affects teaching materials and classroom management (Hughes, 1989). However, within the applied linguistics and language testing community the term 'washback' is more widely used today (Weir 1990; Alderson and Wall 1993; Alderson 2004).

Washback is generally perceived as being either negative (harmful) or positive (beneficial). Negative washback is said to occur when a test's content or format is based on a narrow definition of language ability, and so constrains the teaching/learning context. Davies et al. (1999, p. 225) offer the following illustration:

'If, for example, the skill of writing is tested only by multiple choice items then there

is great pressure to practise such items rather than to practise the skill of writing itself'.

Positive washback obtained when a testing procedure encourages 'good' teaching practice; for example, an oral proficiency test is introduced in the hope that it will promote the teaching of speaking skills.

Each country has introduced different types of assessment in their educational system with regard to promoting the change in teaching and learning process. Hence, test should meet the intention based on the curriculum documents from the institution.

Carr (2011, p. 7) mention some types of assessment or test such as curriculum-related decisions including admission (sometimes including screening) test, placement test, diagnostic test, progress test and achievement test while other decisions types consist of 
proficiency and screening test. Admission test is administered to the students in respect to the program that they have been chosen. Placement test is concerned with decisiononthe level of the particular program. Diagnostic test deals with identifying the learners' weakness and strength with appropriate procedure. Progress test measures how well the students mastering the course and meet the course objectives. Achievement test is used to identify how well the students provide their comprehension to the course objectives and course content.

Furthermore, to construct the assessment Munoz \& Alvarez (2010, p. 34), suggestMunoz \& Alvarez (2010, p. 34), there are some principles of good assessment some principles of good assessment. They are some key points that should be noticed such as:clear criteria that should understandable to both of teachers and students; a variety of tasks objectives at different learning styles; authentic and meaningful tasks; different kind of techniques to build up the interaction among the students and the teacher; encouragement of self assessment; tasks derive from curriculum objectives that should consistent with the instructional practices; ongoing analysis so that the students can explore the extent their abilities and knowledge; and detailed and specific feedback

Those principles may alert the teacher to design and create a sophisticated assessment with the scoring system so that they can provide the useful and correct assessment as a result of learning outcomes.

The tasks are designed to meet the learning objectives and provide the students' opportunity to learn the given topic. In this case, the students are able to explore they ability and knowledge to describe the given pictures with regard to their previous experience about electrical matters and the terms of electrical engineering. The tasks also lead the students to be more active in speaking based on their comprehension to the pictures and also able to communicate their ideas and share to their classmates. It is considered as content-based assessment with given instruction from the teacher in respect to their learning background as non-English Department students. However, the tasks should refer to their needs as future technicians so that the institution can support and manage their needs by clearly stated the instructional objectives which are necessary to the particular study program.

The tests may present positive and negative impact to the teacher, students and the institution as long as the effectiveness of the tasks to develop the students' abilities and meet the demand of the institution and also the work world. 


\section{Methodology}

This study focuses on using classroom action research where the researchers will act as a teacher who teaches English for Electrical Engineering using the framework or model of learner-centered teaching to A and B classes.

\section{Procedure}

Following is the procedure of language assessment concerningthe students who major in Electrical Engineering:

- The students are given the theories about learning how to describe or explain some activities

- During interaction, the teacher may encourage the students to be more active in exploring their opinion, ideas, and even critical thinking about the lesson

- The tasks given to the students are directly linked with the instruction and allow them to make preparation in order to provide well-prepared performance. They can also bring the script or even spontaneously in expressing their thought and opinion directly while the teacher analysis the answer based on the scoring criteria.

- The teacher gives direct feedback and discusses the result with the students as error correction.

The research focuses on the assessment with regard to the curriculum-related tests which concern how well the students comprehend and master the course objectives. The test administered to the students through direct and indirect testing lead to letting the students recall the knowledge of given or previous materials. The test also should meet the reliability because it is related to the scoring system and consistent with the error that may occur in the test.

Following are the evaluation rubric that should be a guidance for the teacher: 


\section{The Evaluation Rubric}

\begin{tabular}{|c|c|c|c|c|c|}
\hline Category & 4 & 3 & 2 & 1 & Score \\
\hline Grammar & $\begin{array}{l}\text { Grammar } \\
\text { covered in class } \\
\text { was used to } \\
\text { communicate } \\
\text { effectively }\end{array}$ & $\begin{array}{l}\text { A few minor } \\
\text { difficulties arise } \\
\text { from not using } \\
\text { the grammar } \\
\text { studied in class }\end{array}$ & $\begin{array}{l}\text { Grammatical } \\
\text { errors led to } \\
\text { many minor } \\
\text { difficulties or } \\
\text { one major } \\
\text { breakdown in } \\
\text { communication }\end{array}$ & $\begin{array}{l}\text { Grammatical } \\
\text { errors severely } \\
\text { hampered } \\
\text { communication }\end{array}$ & \\
\hline Vocabulary & $\begin{array}{l}\text { Vocabularies } \\
\text { studied in class } \\
\text { was used to } \\
\text { express ideas } \\
\text { eloquently }\end{array}$ & $\begin{array}{l}\text { A few minor } \\
\text { difficulties arise } \\
\text { from not using } \\
\text { appropriate } \\
\text { vocabulary }\end{array}$ & $\begin{array}{l}\text { Some } \\
\text { difficulties arise } \\
\text { due to limited } \\
\text { vocabulary } \\
\text { and/or bad } \\
\text { diction }\end{array}$ & $\begin{array}{l}\text { Communicatio } \\
\mathrm{n} \text { was severely } \\
\text { hampered due } \\
\text { to lack of } \\
\text { vocabulary }\end{array}$ & \\
\hline Fluency & $\begin{array}{l}\text { Student acted as } \\
\text { a facilitator, } \\
\text { helping the } \\
\text { conversation } \\
\text { flow and } \\
\text { develop }\end{array}$ & $\begin{array}{l}\text { Some minor } \\
\text { difficulties } \\
\text { maintaining the } \\
\text { conversation } \\
\text { were evident }\end{array}$ & $\begin{array}{l}\text { Some effort was } \\
\text { required to } \\
\text { maintain the } \\
\text { conversation. } \\
\text { There may have } \\
\text { been a few long } \\
\text { pauses }\end{array}$ & $\begin{array}{l}\text { Much effort } \\
\text { was required to } \\
\text { maintain the } \\
\text { conversation. } \\
\text { There may } \\
\text { have been } \\
\text { many long } \\
\text { pauses }\end{array}$ & \\
\hline $\begin{array}{l}\text { Voice and non- } \\
\text { verbal } \\
\text { communication }\end{array}$ & $\begin{array}{l}\text { Clear } \\
\text { pronunciation } \\
\text { and inflection } \\
\text { expressions } \\
\text { were used to } \\
\text { enhance } \\
\text { communication }\end{array}$ & $\begin{array}{l}\text { No serious } \\
\text { problem arise, } \\
\text { but better } \\
\text { pronunciation } \\
\text { inflection, } \\
\text { and/or non- } \\
\text { verbal } \\
\text { communication } \\
\text { could have made } \\
\text { communication }\end{array}$ & $\begin{array}{l}\text { Some } \\
\text { communication } \\
\text { problems arise } \\
\text { due to unclear } \\
\text { pronunciation } \\
\text { and/or lack of } \\
\text { infection and/or } \\
\text { expression. } \\
\text { Other students } \\
\text { may have been } \\
\text { difficult to hear }\end{array}$ & $\begin{array}{l}\text { Pronunciation, } \\
\text { inflection, } \\
\text { and/or } \\
\text { expression } \\
\text { confused } \\
\text { communication } \\
\text {. The student's } \\
\text { voice cannot be } \\
\text { heard }\end{array}$ & \\
\hline
\end{tabular}

Taken from http://www.eslgo.com/resources/sa/oral_evaluation.html

Meanwhile, the validity also plays an important role in the assessment. In this research, the test is considered authenticity when the task refers to the real world as well as the students' program or in a particular target language use (TLU),in this case, the use of English for Electrical Engineering. The tasks are content based using the picture which intended the students to take into consideration on the electrical terminology or glossaries so that they can apply those vocabularies into their daily life and future job. The tests also meet the construct validity because the score is considered important to measure the students' interest on the lesson using the attractive materials. Furthermore, the tasks also have the washback to both of the people and the institution because the test is integrated to the students' 
needs and closely related to their study program so that the institution will support the teaching and learning activities by giving more favorable facilities.

An example of tasks in the classroom:

\section{Task 1}

- $\quad$ Mention some wordsrelated to the pictures

- $\quad$ Describe the picture using the appropriate sentences

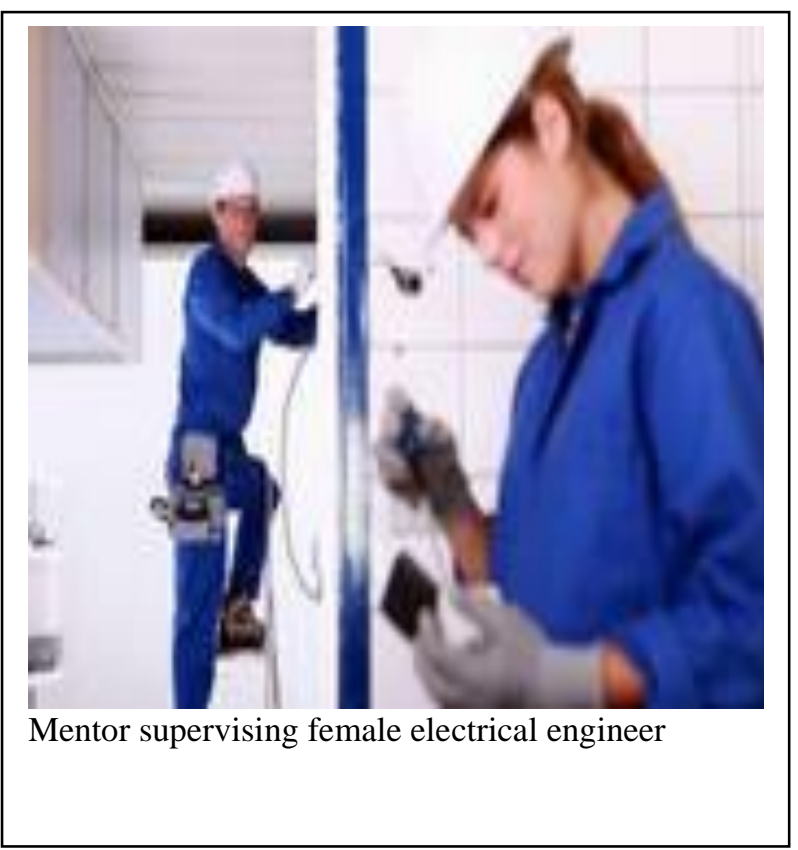

- Give your comment to the following picture and mention some activities based on the picture

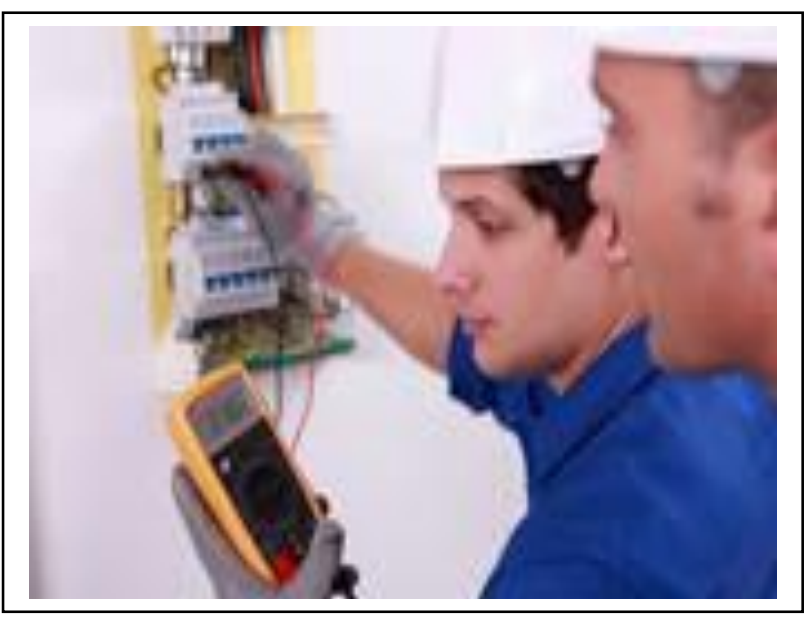




\section{Techniques for Collecting and Analysing Data}

Observation and semi-structured interviews will be used as the means for data collection. Teaching and learning activities happening during this action research study will be videotaped for detailed check. All activities will be carefully observed and analyzed using the five aspects written in the learner-centered framework. Notes will be made while observing or viewing the video for the purpose of accurate analysis.

\section{Results}

Results are presented for the aspects examined in teaching and learning process through the direct observations. The teacher and the students understand the specified class objectives. However, observations showed that there was a significant resulton applying the difference treatment in each class. Both A and B class were given objectives verbally and in writing.

Goal setting is beneficial to students' learning and carrying out activities which are aimed at the achieving those goals is clearly more helpful. Failure in establishing the objectives of the lesson may be detrimental to students as they do not see a clear direction for learning. Also failure in developing activities related to lesson objectives can create confusion on students, which will eventually give negative impact on achievement. A plausible consequence of such failure can result in students' lack of attention which leads to loss of motivation in learning. However, establishing a clear connection among objectives and instruction can help learners feel more motivated to take parts in class, be more aware or expected results, develop self-assessment strategies, detect their own progress or deficiencies, and establish a plan of action.

Washbackis also perceived on the design of assessment tasks. Teacher designs assessment tasks mainly by considering content validity and management of the task. Task design is of utmost importance because students' success during assessment largely depends on the quality of teachers structure activities. Establishing clear steps to develop a task implies determining which details and information teachers want the students to include in their learning process. This can certainly make the assessment more valid and reliable because it allows the teacher to elicit extended chunks of speech from the students.

Class observations showed that assessments and teaching practices are limited to a few tasks. However, the tasks that teachers make differ in two classes (A and B). In other words, students in class A were familiar with the assessment format, but the situations or 
contexts which they were required to apply their knowledge and skills were new. In contrast, the students in class B were assessed through tasks which were identical to instructional ones. A possible explanation might be there is the teacher's lack of planning or the teacher's need to consider that tasks must not be completely new to the students or identical to those used for instruction because both provide incorrect assessment.

Although washback on feedback procedures could not be clearly established, score reporting presented differences between the two classes. The teacher provided score for each aspect of the rubric and assigned a global score. In relation to score reporting, Shoharny (1992) claims that to promote positive washabck, assessment information must be 'detailed, innovative, relevant and diagnostic. In addition, she also suggests that it must 'address a variety of dimensions rather than being collapsed into one general score'. In the reporting, teacher also provided the students with the information about their performance in terms of grades for communicative effectiveness, grammar, vocabulary, and task completion.

In general terms, we can conclude that the students in class $\mathrm{B}$ have a better understanding of the assessment criteria and procedures. They are more knowledgeable about oral language components in the rubric. In fact, they were able to name all aspects and specify important features. Because the teacher provided the students with separate scores for each aspect of the rubric, it allowed the students not only to become familiar with the effectiveness and pronunciation and, consequently, to obtain higher oral score gains. Possible explanations for this might be the emphasis the teacher put to these language components during the instruction and assessment; the students' awareness of the importance of these aspects for communication purposes; or their developed ability to measure aspects which were less tangible before the use of the rubric.

With regards to self -assessment, both teacher's and students' survey indicated a significant difference between the class in relation to the use that students made of the rubric for this practice. The difference between two classes (A and B) may be accounted for by the fact that teacher observe in class B trained the students to use the rubrics for self-assessment. Self-assessment can be related to beneficial washback because it helps learners develop internal criteria for progress and success, and thus develop learner autonomy.

In relation to the score gained, class B had higher achievement than class A mainly in communicative effectiveness, grammar, and pronunciation. This results in matched students, perception of gains in communicative effectiveness and pronunciation. Improvements in oral language may be due to the emphasis the teacher put on assessing not only on linguistic competence but also on communicative competence as a whole. The fact 
that the teacher made use of the assessment system may have helped the students become more conscious of assessment goals, criteria, techniques, thus leading them to target their learning efforts to better performance.

\section{Conclusion}

Washback may have negative and positive impacts. However, to have positive washback, a testing procedure which encourages 'good' teaching practice should be observed.

Obviously, the analysis of language assessment plays an important role in learning activities asit is believed that tests directly influence educational processes in various ways. Goal setting is important for students and this will be reflected in the teaching materials as well as the test.

To conduct activities aimed to achieve those goals is clearly more helpful. Task design is accordingly necessary because students' success during assessment mostly depends on the quality of teacher's structured activities. One common assumption is that teachers will be influenced by the knowledge that their students have. The will then design the test in line with the goals and will adapt their teaching methodology and lesson content to reflect the test's demands.

\section{References}

Antoniazzi, María I. Casado. (2012) "ICTs Applied to Formal Foreign Language Aural-oral 9 Assessment: ORALEX* and Communicative Language Competences in English", Journal of Language Teaching and Research.

Carr, NT 2011, 'What are we testing and why? Designing and analysing language tests', Oxford: Oxford University Press, pp. 5-23.

Cheng, L 2008, 'Washback, impact and consequences. In E. Shohammy\& N. H. Hornberger (Eds.), Encyclopedia of language and education ( $\left.2^{\text {nd }} e d\right)$, Vol. 7, New York: Springer.

Finch, AE 2002, 'Authentic assessment: Implications for EFL performance testing in Korea, Secondary Education Research, Vol. 49, pp. 89-122.

Folse, KS 2008, 'Six vocabularies activities for the English language classroom', English Teaching Forum, No. 3, pp. 12- 21.

Fulcher, G 2003, 'Chapter 3: Tasks for second language speaking tests. In Testing second language speaking, London: Pearson Longman.

Lightbown, PM 2000, 'Classroom SLA research and second language teaching, Applied Linguistics, Vol. 21, No. 4, pp. 431-462.

Milanovic, M 2002, 'Common European framework of reference for languages: Learning, teaching, assessment (language examining and test development)', Language Policy Division, Strasbourg, pp. 1-59.

Munoz, AP \& Alvarez, ME 2010, 'Washback of an oral assessment system in the EFL Classroom', Language Testing, Vol 27, No. 1, pp. 33-49. 
Ruso, N, ' The influence of task based learning on EFL classroom', Asian EFL Journal, pp. $1-23$.

Richards, JC \& Rodgers, TS 2001, 'Chapter 19: The post-methods era. In Approaches and methods in language teaching ( $2^{\text {nd }} e d$.), Cambridge: Cambridge University Press.

Taylor, Lynda 2005, 'Washback and impact', ELT Journal, Vol. 59, No. 2, pp. 154-155, Oxford University Press

Vecino, AM 2006, 'Using storytelling with adult EFL learners: an enriching classroom experience, Colombian Applied Linguistics Journal, No. 8, pp. 254-274.

Vernier, S., et al, 'The five language skills in the EFL classroom', Universidad Nacional de Cuyo, pp. 1-29. 